\title{
Stolen hearts, Stolen Generations
}

\author{
Winnie Wang \\ University of Technology Sydney, Faculty of Arts and Social Sciences, PO Box 123, Ultimo NSW \\ 2017, Australia. winnie.wang@student.uts.edu.au
}

DOI: https://doi.org/10.5130/nesais.v4i1.1532

Twenty years since Stolen debuted in Melbourne's Playbox Theatre, the play still resonates with audiences as one of the key texts exploring the constructed and contested nature of Australia's Stolen Generations. Its timelessness is owed to the interpretability of theatre, but also to the thoughtful construction in its superb writing. Stolen has continued to prove its relevancy in Australia's negotiation with its Indigenous population, from its plural histories to its ongoing attempts at reconciliation. Stolen is a poignant exploration of the intersection between history and memory, and the role human experiences have to play in building a more inclusive, shared history on Australian soil.

Stolen gives emotional resonance to a political issue by relaying an important episode of Australian history through the exploration of human responses to the collapse of past certainties - happiness and resilience alongside grief and guilt. Such themes become central to the collective memory of Aboriginal experiences of assimilation policies, and work to support the legacy of Stolen. In a sense, the experiences portrayed in Stolen resemble the small truths that augment the 'central truths' that define the parameters of historical reporting (Read 2002). Having undergone the generational reverberations of Aboriginal storytelling in theatre, what has remained fixed is the play's broader socio-cultural context. Harrison challenges the progressional telling of Australian history by stating that colonisation and the Stolen Generations define Aboriginal people today as an indivisible part of their lived reality (Harris 2018).

Stolen was completed in the aftermath of the Human Rights and Equal Opportunity Commission report Bringing Them Home. Backgrounded by the historical moment, the play interestingly does not make reference to this context, but rather highlights the experiential nature of separation. The play is also aptly named Stolen to shift the focus from the contentious debates surrounding the validity of Stolen Generation claims in public and political discourse to instead centre on separation narratives affecting real people. The audience's ability to contextualise these small strands of personal memory into the larger socio-historical landscape of the Stolen Generations serves to legitimise claims of forced removal whilst muddying the "waters of certainty or complacency" (Read 2002, p. 60). 
In the play, whilst Anne was largely ambivalent about her Aboriginality and, perhaps to some degree, even spurned her Aboriginal identity, Sandy held a deep connection to Indigenous culture in practicing oral myth-telling in his performance of the 'Story of the Mungee' (Harrison 2002). These contrasting characters are portrayed with agency, despite experiences of abuse. This also reveals a breadth of experience that has been kept out of public discourse, rendering "debates over culpability and semantics" (Sutherland 2003, n.p.) irrelevant in the face of such resilience amongst suffering.

Importantly, Stolen challenges the notion of a teleological approach to history and critiques our attempts to fit the stories of Aboriginal lived experience into preconceived notions of written history. By rejecting a linear or chronological structure for the storyline, Stolen brings to the forefront of the audience's awareness that the story of the Stolen Generations is not one single story. The nature of exploring memory embedded within a time and place is that despite the fixity of context, human experiences are diverse, coloured and filled with disparities and contradictions. As such, the narrative of the Stolen Generations may be better understood as a matter of 'narrative accrual' (Attwood 2001, p. 183) or 'narrative coalescence' (Attwood 2001, p. 183).

Furthermore, the episodic nature of the script differentiates itself from being just another play preaching about the pain and sorrow of the Stolen Generations. Instead, the absence of a coherent plotline provides windows of insight into the varying experiences and identities that feature in the Stolen Generations narrative. The events, which unfold kaleidoscopically, engage audiences through empathy and reflection stimulated in the absence of definite meaning (Harris 2018). According to Harrison herself:

These are the sort of stories you need to have visceral responses to, not just see statistics and facts. You need to feel what it's like. Theatre is beautiful for that. You've got a darkened room, you've got five real people in front of you and they're sharing a journey and an experience. It's not just a piece of entertainment. (Harris 2018, n.p.)

To reflect the trauma of forced removal, the play attempts to redefine theatre stylistically and to establish new actor-audience relationships. The use of dramatic irony draws audiences into the meaning-making process by setting them on a trajectory of uncovering deeper, more personal truths. Ruby's story is largely told through songs and nursery rhymes, drawing upon a childlike innocence to emphasise, by way of contrast, the corruption evident in the system. In 'Cleaning Routine 2', the repetition of the chorus, "Because we love to work like slaves, we all adore to work like slaves. It puts a rose in every cheek," (Harrison 2002, p. 19) shows the way society primed these children's beliefs and deprived them of a carefree, innocent childhood. In previous productions, the lyrics are sung to the tune of We're Happy Little Vegemites, a 1950s advertisement depicting Australian children as healthy citizens within a prosperous nation. Drawing upon this intertextuality, it can be concluded that the only childhood these children were given was a falsehood. The tune of an upbeat jingle merely serves to obscure the destruction of innocence represented by the lyrics.

In light of the reconciliation process today, Stolen gives voice to Indigenous interests by being an exemplary text in communicating the stories so central to Indigenous identity in contemporary Australia. In refuting claims that sharing histories is about collecting and collating experiences into a simple, linear, coherent narrative of events, Goodall states that Aboriginal people "had a strong sense 
of responsibility and custodianship and the storytelling role of their histories" (Goodall 2002, p. 11). The hopes of creating a forum for Aboriginal voices to be "heard respectfully, and, hopefully with some understanding and sympathy," (Goodall 2002, p. 11) is realised in theatre. As a society, we have much to learn from the powerful telling and re-telling of our own history.

Harrison claims that in writing Stolen, her guiding motivation was to express the idea of five individuals bound to a traumatic past that could not be changed, but also realising that this very event is a shared and immovable experience (Harris 2018). At once a reflection of the tragedies that happened on Australian soil and a celebration of human strength in the face of adversity, Stolen has continued to reinforce that "histories are not sequences of stable facts which can be added and subtracted to reach the unarguable truth, but are instead interpretive narratives" (Goodall 2002, p. 12). The power in theatre is its immediacy in being able to share, fundamentally, what it is to be human arguably something we need more of today.

\section{References}

Attwood, B. 2011, 'Learning about the truth' The Stolen Generations narrative', in B. Attwood \& F. Magowan (eds), Telling Stories. Indigenous history and memory in Australia and New Zealand, Bridget Williams Books, Wellington, pp. 183-212.

Harris, L.C. 2018, 'Stolen has become "more than us” says playwright Jane Harrison', Audrey Journal, 25 April, viewed 28 April 2018, <https://www.audreyjournal.com.au/arts/stolen-has-becomemore-than-us-says-playwright-jane-harrison/>.

Harrison, J. 2002, Stolen, Strawberry Hills Press, NSW.

Goodall, H. 2002, 'Too early or not soon enough? Reflections on 'sharing' histories as process not collection’, Australian Historical Studies, vol. 33, no. 118, pp. 7-24.

https://doi.org/10.1080/10314610208596176

Sutherland, V. 2003, 'Irony lightens 'stolen' tales', The Age, 9 April, viewed 1 May 2018, $<$ https://www.theage.com.au/articles/2003/04/09/1049567729494.html>.

Read, P. 2002, 'Clio or Janus? Historians and the Stolen Generations,' Australian Historical Studies, vol. 33, no. 118, pp. 54-60. https://doi.org/10.1080/10314610208596179

(c) (1) (C) 2018 by the author(s). This article is distributed under the terms and conditions of the Creative Commons Attribution license (http://creativecommons.org/licenses/by-nd/4.0/). 